\title{
Effects of Exogenous Application of Protocatechuic Acid and Vanillic Acid to Chlorophylls, Phenolics and Antioxidant Enzymes of Rice (Oryza sativa L.) in Submergence
}

\author{
Tran Dang Xuan ${ }^{1, * * 10}$ and Do Tan Khang 2 (1) \\ 1 Graduate School of International Development and Cooperation, Hiroshima University, \\ Higashi-Hiroshima City 739-8529, Japan \\ 2 Biotechnology Research and Development Institute, Can Tho University, \\ Can Tho City 902070, Vietnam; dtkhang@ctu.edu.vn \\ * Correspondence: tdxuan@hiroshima-u.ac.jp; Tel: +81-82-424-6927
}

Received: 15 February 2018; Accepted: 6 March 2018; Published: 9 March 2018

\begin{abstract}
In this study, effects from application of protocatechuic acid (PA) and vanillic acid (VA) and their mixture on the submergence tolerance of rice were examined. The treatment of $0.01 \mathrm{mM}$ PA and VA did not show significant increase of rice growth as compared to the controls. However, at higher concentrations $(0.1-1.0 \mathrm{mM})$, rice shoot was elevated in submergence by $20.8-22.4 \%$. The survival percentage of rice seedlings at any dose of PA, VA and their mixture was significantly higher than the controls. In general, the mixture of PA and VA was more active to promote shoot elongation and survival in submergence than sole treatment of either PA or VA. The amount of chlorophyll $b$ by PA was significantly increased, while no change in chlorophyll $a$ content was observed. VA remarkably reduced malondialdehyde quantity at three days of submergence, while no significant difference among treatment was observed in PA, the mixture, and respective controls. The two phenolic acids promoted contents of phenolics and flavonoids in rice leaves and roots, however the quantities of endogenous PA and VA in rice were not markedly differed after PA and VA treated on roots of rice seedlings. The ascorbate peroxidase and superoxide dismutase activities were enhanced, while the expression of genes encoding antioxidant enzymes was favored. VA increased the expression level of ascorbate peroxidase genes in higher levels than PA and their mixture, while no significant difference was observed in the other genes including superoxide dismutase, catalase, glutathione reductase, and peroxidase. Findings of this study showed that PA and VA increased the submergence tolerance of rice by promoting the photosynthetic and anti-oxidative processes in rice seedlings. The treatment of PA and VA mixture on seedling roots was potent to promote the submergence tolerance in rice.
\end{abstract}

Keywords: antioxidant enzymes; exogenous application; root treatment; protocatechuic acid; submergence tolerance; rice; vanillic acid; mixture

\section{Introduction}

Submergence substantially causes major limitations on productivity and viability of agricultural crops worldwide. Among important crops, rice (Oryza sativa L.) is mostly affected by submergence stress since many rice landraces are primarily cultivated in lowland and flood-prone areas [1]. There are annually more than 20 million hectares of paddy fields in the world exposed to flood or submergence [2]. The Mekong and Red River deltas of Vietnam, the Ayeyerwaddy delta of Myanmar and the Ganges-Brahmaputra delta of Bangladesh, the central rice production areas worldwide, have been faced with submergence [1,3]. 
In recent years, many submergence-tolerant rice varieties have been generated using both conventional and DNA marker-assisted selection approaches. The SUB1 QTL (quantitative locus trait) [4], which included three ethylene response factor-like genes (SUB1A, SUB1B, and SUB1C) [4,5], and controlled by the SUB1 gene determining the submergence tolerance, was identified. In addition, the SNORKEL1 and SNORKEL2 genes [6] which involved in the rapid elongation response of deep water rice, respectively, were detected. Success in using the SUB1 gene has provided the development of many submergence tolerance varieties [2]. However, the fact that many varieties make limited recovery after submergence exposure is one of the practical problems of those methods. Specifically, limited recovery may detrimentally affect physiological development and reproduction with significant reductions in the total productivity [7]. In addition, the moderately submergence-tolerant varieties are normally low in both yield and quality [8]. Therefore, improving the submergence tolerance of the current rice varieties by enhancing their physiological processes using exogenous regulatory factors during submergence is one of the promising solutions [9].

Ecologically, rice can survive under water for a short period due to adaptive physiological mechanisms including enzymatic and non-enzymatic factors [10,11]. Regarding the former factor, an antioxidant enzyme system has been discovered in plants subjected to biotic and abiotic stresses producing numerous varieties of activated oxygen species consisting of superoxide, singlet oxygen, hydroxyl radicals, and hydrogen peroxide [12,13]. In fact, superoxide dismutase (SOD) is initially activated to convert superoxide to oxygen and hydrogen peroxide. The three major enzymes, namely catalase (CAT), glutathione peroxidase (GPx), and ascorbate peroxidase (APX) subsequently cleavage hydrogen peroxide, a dangerous oxygen-containing free radical, into water molecules [14-17]. Damanik et al. [16] highlighted the increase of SOD, CAT, APX and glutathione reductase (GR) activities in Malaysian rice cultivars after eight days of complete submergence, and supposed that if these antioxidant enzyme activities were promoted during excess water stress, the level of tolerance would be increased. In terms of the non-enzymatic mechanism in submergence responses, phenolics have been reported to have strong scavenging capacity of free radicals relating to oxidative stress [18]. Particularly, a marked increase in total phenolic content was recorded in plants during exposure to UV light [19,20], saline stress [21,22], drought stress [23], and flooding condition [24].

It is estimated that over 20 million ha in rainfed lowland areas are detrimentally influenced by flood annually [2]. These areas are subjected to either frequent flash flood or submergence, including longer-term flooding (20-50 cm) (partial/stagnant, semi-deep), deep water $>100 \mathrm{~cm}$, and very deep water (up to 3-4 m) (in floating rice areas). Rice productivity has been adversely reduced (averaging about 1.5 tons / ha) because of the lack of rice cultivars tolerant to submergence stress [2]. The flooding can be classified into: flooding during germination (anaerobic germination), a problem when direct seeding is practiced and affected by heavy rain; flash flood (submergence), where rice plants are completely submerged for up to two weeks, thus submergence tolerance is required for this condition; stagnant flooding, where the water depth is up to $50 \mathrm{~cm}$, and flooding occurs more than two weeks to several months, hence rice varieties tolerant of stagnant flooding are required; and deeper stagnant flooding, where the water depth is from $>50 \mathrm{~cm}$ to $1 \mathrm{~m}$ or more. That needs rice cultivars with tall plant height or rapid internode elongation [2]. However, the anaerobic flooding during germination and flash flood caused detrimental reduction on rice growth and yields, as rice cultivars being cultivated are often non-submergence tolerance. Countermeasures to lower the harmful affect attributed to anaerobic flooding and submergence are needed.

There have been several attempts to increase the submergence tolerance of rice. For example, post-flood $\mathrm{N}$ application either as broadcasting or spray markedly promoted survival, photosynthesis, anti-oxidant activity, and rice yield, while pre- and post-submergence Si spray detrimentally affected elongation, lodging, leaf senescence, and chlorosis [25]. Ethylene-air treatment stimulated internode elongation, and thus stimulated growth in submerged floating rice plants [26]. Nutrient application at the seedling stage [27], and post-submergence $\mathrm{N}$ and basal $\mathrm{P}$ application increased plant survival and 
productivity of rice [25]. However, either pre- or post-application of nutrients may severely affect rice yield and quality and require heavy labor force in fields.

In our previous study, it was reported that the quantities of protocatechuic acid (PA) and vanillic acid (VA) in rice seedlings were significantly increased (6.50 and 2.89 folds, as compared to the non-treated rice, respectively) when rice seeds were treated in anaerobic flood during germination [24]. However, the responses of the two compounds to the water depth $(5$ and $10 \mathrm{~cm})$ differed. This study was therefore conducted to examine the exogenous applications on rice roots of PA, VA, and their mixture to examine the efficacy on the elevation to rice growth in submergence. The influences on chlorophyll contents, lipid peroxidation, antioxidant enzyme activities and gene expression were also investigated.

\section{Results}

\subsection{Effects of Exogenous Application of PA and VA on Rice Growth}

Table 1 shows the effects from treatments $(0.01,0.1$, and $1.0 \mathrm{mM}$ doses) of PA, VA and their mixtures on shoot height of rice. The elevation of shoot height was the most important in submergence tolerance, thus only the criterion of rice emergence was measured. At the lowest dose $(0.01 \mathrm{mM})$, both PA and VA did not significantly elevate shoot height of rice, but their mixture promoted rice growth by $15.7 \%$ in submergence, as compared to the respective controls (Table 1). The shoot height was remarkably promoted by $0.1-1.0 \mathrm{mM}$ doses by single treatments of either PA or VA, and their mixture, however the levels of elevation were not significantly different among applied doses and compounds. Findings in Table 1 revealed that the mixtures of PA and VA were more effective to elevate rice growth in submergence than either sole PA or VA treatment. The dose $0.1 \mathrm{mM}$ was therefore selected to examine the changes in chemical components, antioxidant enzymes and gene expression by PA and VA application.

Table 1. Effects of exogenous application of phenolic acids on shoot height of rice in submergence.

\begin{tabular}{cccc}
\hline Treatments & Shoot Height $(\mathbf{c m})$ & Survival Percentage & Scale \\
\hline Control & $5.19 \pm 0.08^{\mathrm{c}}(0.0)$ & $75.56 \pm 6.46^{\mathrm{d}}$ & 5 \\
PA 0.01 & $4.56 \pm 0.38^{\mathrm{c}}(12.1)$ & $83.33 \pm 4.35^{\mathrm{c}}$ & 5 \\
PA 0.10 & $5.63 \pm 0.38^{\mathrm{b}}(-8.48)$ & $95.56 \pm 3.51^{\mathrm{b}}$ & 3 \\
PA 1.00 & $6.27 \pm 0.28^{\mathrm{ab}}(-20.8)$ & $100.00 \pm 0.00^{\mathrm{a}}$ & 1 \\
VA 0.01 & $4.45 \pm 0.36^{\mathrm{c}}(14.26)$ & $85.19 \pm 5.67^{\mathrm{c}}$ & 5 \\
VA 0.10 & $5.46 \pm 0.17^{\mathrm{b}}(-5.20)$ & $96.30 \pm 2.65^{\mathrm{b}}$ & 3 \\
VA 1.00 & $6.37 \pm 1.41^{\mathrm{ab}}(-22.4)$ & $96.67 \pm 1.33^{\mathrm{b}}$ & 3 \\
M 0.01 & $6.01 \pm 0.61^{\mathrm{ab}}(-15.7)$ & $97.78 \pm 0.23^{\mathrm{b}}$ & 3 \\
M 0.10 & $6.16 \pm 1.03^{\mathrm{ab}}(-18.69)$ & $100.00 \pm 0.00^{\mathrm{a}}$ & 1 \\
M 1.00 & $6.33 \pm 2.96^{\mathrm{a}}(-21.97)$ & $100.00 \pm 0.00^{\mathrm{a}}$ & 1 \\
\hline
\end{tabular}

PA: Protocatechuic acid; VA: vanillic acid; M: Mixture of PA and VA; 1.0, 0.1, and 0.01 are different dilution at 1.0, 0.1, and $0.01 \mathrm{mM}$; Scale 1: 100\%, 3: 95-99\%, 5: 75-94\% survival (Table A1); Different letters in same column indicate significantly difference at $p<0.05$; Values in columns are means $\pm \mathrm{SD}$ (standard deviation); Values in the parentheses are inhibition over control (\%). Minus values in parentheses are promotion over control (\%).

Results in Table 1 showed that the treatments of PA and VA at any dose significantly increased the survival percentage of rice in submergence. At $1.00 \mathrm{mM}$ of PA, and mixture at $0.10-1.00 \mathrm{mM}$ of the mixture, no injury on rice survival was observed. Both PA and VA showed similar tolerance level at $0.10 \mathrm{mM}$, which was lower than their mixture. At $0.01 \mathrm{mM}$, both PA and VA exhibited comparable tolerance strength that was remarkably higher than the control, but was lower than their mixture. The mixture of PA and VA at any dose exhibited higher survival percentage than either PA or VA (Table 1). Regarding the evaluation by survival scale, application of VA and PA at $0.01 \mathrm{mM}$ did not show different survival scale compared to the control (Table 1). However, at 0.10-1.0 mM, both VA and PA increase the survival of rice seedling, and PA showed greater survival at the maximal dose 
$(1.0 \mathrm{mM})$ than VA. Combination of both PA and VA showed greater survival strength than the single application of either PA or VA (Table 1).

\subsection{Effects of Exogenous Application of PA and VA Photosynthetic Pigments and Lipid Peroxidation}

Figure 1 shows the content of chlorophyll $a$ and $b$ in rice seedlings under submergence with phenolic acid pre-treatment. After $24 \mathrm{~h}$ soaking with $0.1 \mathrm{mM} \mathrm{PA}, \mathrm{VA}$, and the mixture, the chlorophyll $a$ in rice leaves was maintained at a steady level at either three days or six days after pre-treatment. However, the content of chlorophyll $b$ was $40 \%$ higher than that of the control $(p<0.05)$ after rice seedlings treated with PA for three days. After three days, VA caused a significant reduction of $>50 \%$ in the malondialdehyde (MDA) content $(p<0.05)$, while the content of each of phenolic acid treatment after six days was still relatively comparable to that of the control (Figure 1).
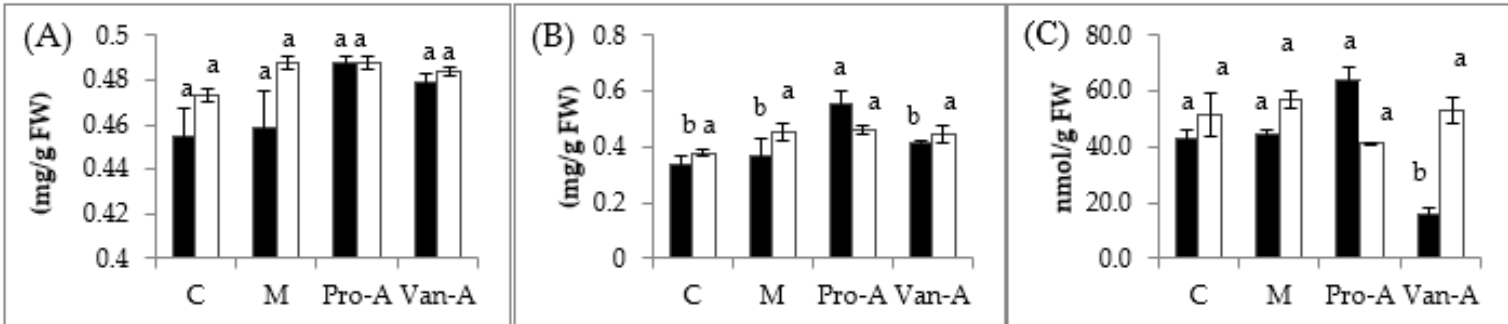

Figure 1. Changes of: chlorophyll $a$ (A); chlorophyll $b$ (B); and MDA (C) contents of rice after pre-treatment with PA and VA. Black column (three days after submergence) and white column (six days after submergence); C: Control, M: Mixture, Pro-A: Protocatechuic acid, Van-A: Vanillic acid; Means with different small letters in the same column color are significantly different $(p<0.05)$; FW: Fresh weight; MDA: malondialdehyde.

\subsection{Effect of Exogenous Application of PA and VA on Total Contents of Phenolics and Flavonoids, and Endogenous PA and VA}

The total phenolic and flavonoid contents of rice seedlings considerably were changed during submergence after pre-soaking in exogenous PA and VA (Figure 2). All treatments significantly improved the total phenolic contents in leaves $(p<0.05)$. In contrast, the tremendous reduction of both total phenolic and flavonoid contents was recorded in roots after pre-treatment. Total phenolic contents were significantly increased in rice leaves by PA, VA, and their mixtures. However, total flavonoids were markedly promoted only by sole application of either PA or VA, whereas their mixture was statistically similar to the respective control (Figure 2). Treatments of either PA or VA, or their mixture did not change endogenous contents of PA and VA in rice leaves and roots (Figure 2).

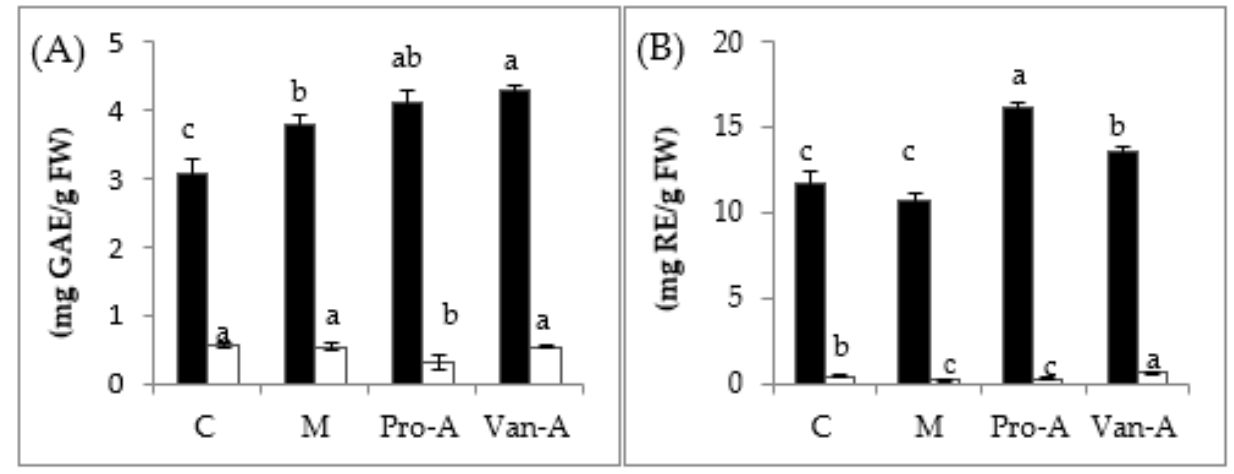

Figure 2. Cont. 


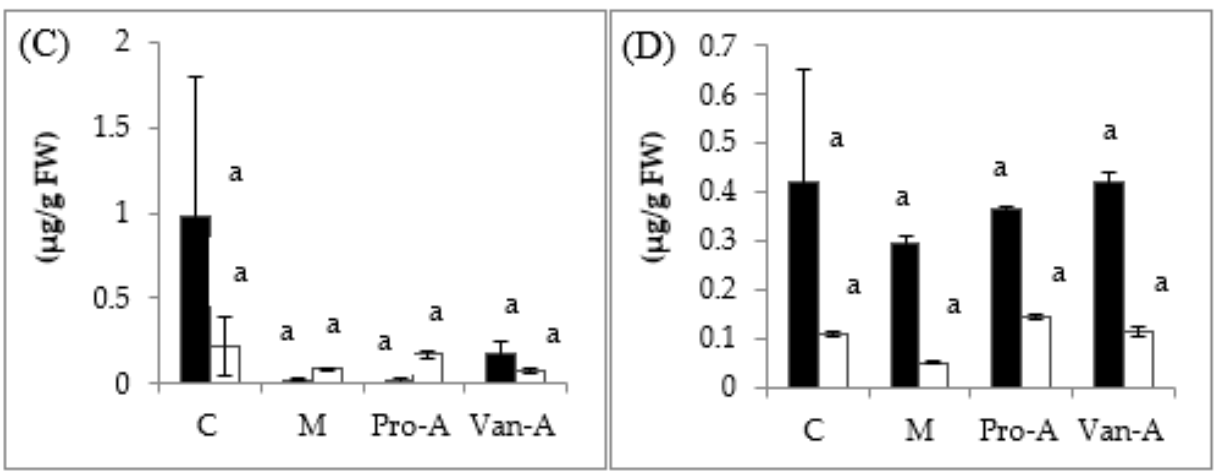

Figure 2. Variation of: total phenolic (A); total flavonoid (B); protocatechuic acid (C); and vanillic acid (D) contents in rice after pre-treatment with PA and VA. Black column (leaves) and white column (roots). Means with different small letters in the same column color are significantly different $(p<0.05)$; FW: Fresh weight, GAE: Gallic acid equivalent, RE: Rutin equivalent.

\subsection{Effect of Exogenous Phenolics on Antioxidant Enzymes}

The changes in antioxidant enzyme activities after pre-soaking with phenolic acids are shown in Figure 3. The catalase activity was not affected by the phenolic acid pre-treatments in submergence stress after three days. However, after six days, the catalase activity greatly increased by VA and the mixture pre-treatments $(p<0.05)$. The SOD activity was markedly enhanced with both PA and VA pre-treatment, which was more than three-fold increase compared to the control after three days. All treatments significantly increased the activity of APX after three days and six days of submergence. PA pre-treatment substantially increased the APX activity after three days. However, after six days, the rise of the APX activity was caused by protocatechuic acid pre-treatment. Regarding to the peroxidase (POD) activity, the mixture was more effective than either PA or VA increasing the activity by approximately $14 \%$, compared to the control $(p<0.05)$. No influence of PA, VA, and their mixture on the glutathione reductase (GR) activity was found.
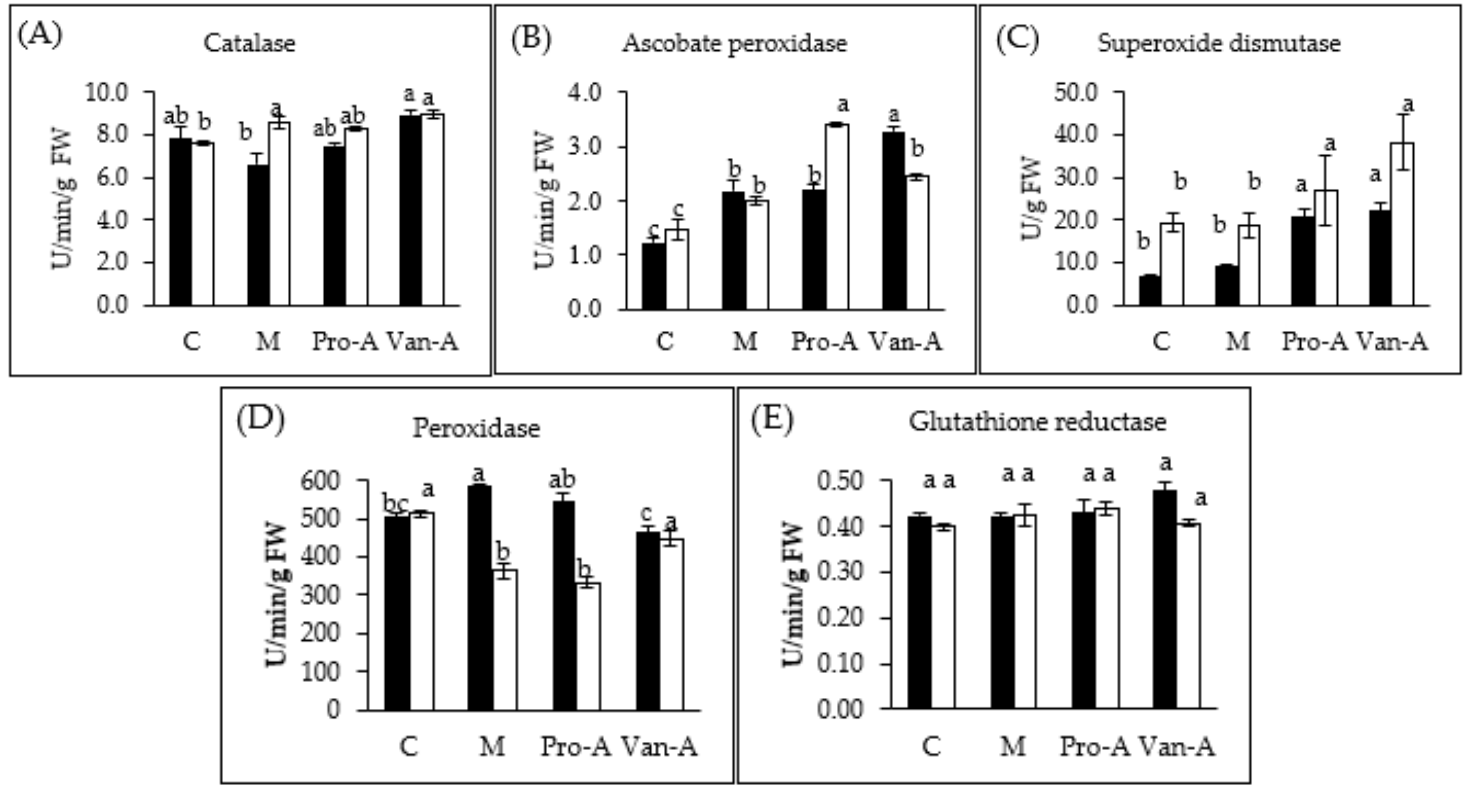

Figure 3. Changes of: catalase (A); ascobate peroxidase (B); superoxidase (C); peroxidase (D); and glutathione reductase (E) activities in rice after pre-treatment with PA and VA. Black column (three days after submergence) and white column (six days after submergence). Means with different small letters in the same column color are significantly different $(p<0.05)$. 
The transcript of antioxidant enzyme genes was slightly enhanced by the phenolic acid treatments compared to the control. Most of the relative expression levels were lower than 1, except APX gene under the VA treatment, which was significantly higher than the PA and the mixture treatments. There was no significant difference in the expression of superoxidase (SOD), catalase (CAT), POD, and GR among three treatments.

\subsection{Coefficient Correlations among Contents of Total Phenols, Flavonoids, Chlorophylls a and b, Lipid Peroxidation, and Gene Expression of Antioxidant Enzymes}

Results in Table 2 showed that the $R^{2}$ values of total phenolics were significantly proportional to contents of total flavonoids (0.579) and chlorophyll $a(0.579)$ at $p<0.05$, and SOD (0.818) and APX (0.865) at $p<0.01$, whereas no significance difference with chlorophyll $b$ and CAT, POD, and GR was observed. Total flavonoids were markedly proportional to contents of chlorophyll $a(0.640, p<0.05)$, and chlorophyll $b(0.797, p<0.01)$. Significantly increases were observed in the lipid peroxidation and POD $(0.680, p<0.01)$, chlorophyll $a$ and SOD $(0.644, p<0.05)$, SOD and APX $(0.721, p<0.05)$, whereas reverse reduction was observed in CAT and POD $(-0.773, p<0.01)$, and POD and GR $(0.702, p<0.05)$. The contents of chlorophylls $a$ and $b$ were significantly proportional $(0.832, p<0.01)$ (Table 2$)$.

Table 2. Correlation $\left(R^{2}\right)$ among measured parameters relating to phenolics, flavonoids, lipid peroxidation, chlorophylls and antioxidant enzyme activities.

\begin{tabular}{|c|c|c|c|c|c|c|c|c|c|c|}
\hline & Phenolics & Flavonoids & MDA & Chla & Chlb & CAT & SOD & APX & POD & $\overline{\mathrm{GR}}$ \\
\hline Phenolics & 1 & & & & & & & & & \\
\hline Flavonoids & 0.579 * & 1 & & & & & & & & \\
\hline MDA & -0.158 & 0.309 & 1 & & & & & & & \\
\hline Chla & 0.579 * & 0.640 * & 0.030 & 1 & & & & & & \\
\hline Chlb & 0.521 & $0.797 * *$ & 0.364 & $0.832 * *$ & 1 & & & & & \\
\hline CAT & 0.228 & 0.216 & -0.565 & -0.120 & -0.187 & 1 & & & & \\
\hline SOD & $0.818^{* *}$ & $0.793 * *$ & -0.188 & $0.644^{*}$ & 0.566 & 0.413 & 1 & & & \\
\hline APX & $0.865^{* *}$ & 0.291 & -0.542 & 0.322 & 0.178 & 0.484 & $0.721 * *$ & 1 & & \\
\hline POD & -0.090 & -0.219 & $0.680^{*}$ & -0.100 & 0.044 & $-0.773^{* *}$ & -0.398 & -0.274 & 1 & \\
\hline GR & 0.364 & 0.208 & $-0.630 *$ & 0.336 & 0.135 & 0.470 & 0.564 & 0.510 & $-0.702 *$ & 1 \\
\hline
\end{tabular}

${ }^{*},{ }^{* *}$ : correlation is significant at the 0.05 and 0.01 level, respectively; CAT: Catalase; GR: Glutathione reductase; SOD: Superoxidase; POD: Peroxidase; APX: Ascorbate peroxidase; MDA: Malondialdehyde; Chla: Chlorophyll $a$; Chlb: Chlorophyll $b$.

\section{Discussion}

In our previous study, thirty rice cultivars were treated at 5 and $10 \mathrm{~cm}$ anaerobic flooded condition, and it was found that the cultivar Koshihubo was the maximum tolerant [24]. It was found that the number and quantity of phenolic acids were strongly increased during treatment, but they were varied among compounds and depth levels of the anaerobic flooding. In detail, five phenolic acids, PA, chlorogenic acid, VA, benzoic acid, and cinnamic acid, were found in the controls (non-treated plants), of which contents of PA, benzoic acid, and cinnamic acid were significantly increased at $10 \mathrm{~cm}$ depth, while quantities of VA and chlorogenic acid exerted remarkable extents at $5 \mathrm{~cm}$ depth, but were significantly reduced at $10 \mathrm{~cm}$ depth. PA was selected because the accumulation of this compound was higher (6.50 folds), than benzoic acid (1.77 folds) and cinnamic acid (2.91 folds). Similarly, that of VA was higher (2.89 folds) than chlorogenic acid (2.68 folds) [24]. The two compounds were proposed to play a role in the tolerance of rice in anaerobic flooding germination but the responses to the depth of anaerobic flooding (5 and $10 \mathrm{~cm}$ ) were differed. Hence, PA and VA were used to examine their efficacy on the submergence tolerance in this study.

It was found that the application of PA, VA and their mixtures showed potent stimulation on rice growth in submergence, however the elevated levels were dose-dependent. At $0.01 \mathrm{mM}$, the mixture showed stronger stimulation on elongation of rice shoot than sole application of either PA or VA. Although no significant difference among $0.01,0.1$ and $1.0 \mathrm{mM}$ doses of the mixture was observed, in general, the mixture at $1.0 \mathrm{mM}$ exerted remarkably higher elevation than the dose $0.1 \mathrm{mM}$ of either 
PA or VA (Table 1). Findings in Table 1 indicated that the mixture of PA and VA was more active to stimulate rice growth in submergence than individual treatments of either PA or VA.

Chlorophylls play an extremely crucial role in plant photosynthesis. Numerous previous studies reported that, under submergence stress, the chlorophyll content in leaves massively declined due to high ethylene concentration [28] or carbohydrate accumulation, or light and oxygen insufficiencies [29-34]. $\mathrm{Wu}$ and Yang [35] reported the significant decrease of chlorophyll $a$ and $b$ and total contents after a submergence treatment of 14-day old rice seedlings. Moreover, chlorophyll reduction greatly influences on photosynthetic efficiency affecting the normal growth of the plant $[9,36]$. In this study, the chlorophyll $b$ content was considerably alleviated by exogenous protocatechuic acid pre-treatment. A similar study also reported the enhance of chlorophyll content due to phenolic acid (salicylic acid) pre-soaking [36]. Briefly, PA and VA pre-treatments could increase the level of chlorophyll content that would result in the photosynthetic improvement during submergence period. Basically, chlorophyll content is degraded by many environmental factors, e.g., submergence stress. The degradation of chlorophyll is regulated by an enzyme system, and chlorophyllase is one of the most important enzymes [37]. Yang et al. [38] reported that phenolic acids including $o$-hydroxyphenyl acetic, ferulic and $p$-coumaric acids with high concentrations (50 to $200 \mathrm{ppm}$ ) significantly stimulated the activities of chlorophyllase $a$ and $b$ of rice seedlings. This finding proved that there is a close correlation between phenolics and chlorophyll contents in rice. Therefore, the increase of the chlorophyll $b$ content might involve in the inhibitory activity of protocatechuic acid on chlorophyllase activity the applied dose was low $(0.1 \mathrm{mM})$, equivalent to about $0.015 \mathrm{ppm}$. Moreover, the changes of chlorophyll $a$ and $b$ contents positively correlated to the total endogenous phenolic contents. It could be concluded that the treatments of PA and VA indirectly activated the increase of endogenous phenolics and flavonoids correlated to the non-enzymatic anti-oxidative mechanism of rice under submergence.

Under stress conditions, lipid peroxidation occurs in plant cells and results in severe injuries in plant tissues. MDA, a reactive aldehydic product, is formed by lipid peroxidation during degradation process in biological cells [9,39]. Lu et al. [40] reported that the lower is the MDA content detected in tissues, the lesser is the cell damage that takes place during exposing to stressful conditions. As a result, the level of tolerance was improved [16]. The result in this study highlighted that exogenous VA pre-treatment notably reduced MDA content in rice under submergence at the seedling stage. One of possible reasons for the reduction of lipid peroxidation in rice was the substantial increase of total phenolic and flavonoid contents after being pre-soaked with PA and VA. Basically, among secondary metabolites, phenolics are one of the most important classes of compounds possessing antioxidant activity, especially lipid peroxidation inhibition. The presence of hydroxyl and carbonyl groups (playing a major role in neutralizing free radicals) in an aromatic ring is the most vital characteristic of this group of bioactive compounds [41]. In the case of lipid peroxidation, phenolic compounds lock the lipid alkoxyl radicals, and the more hydroxyl groups a phenolic compound has in the aromatic ring, the more radicals would be trapped [42]. In addition, VA and PA are strong antioxidants abundantly found in plants [43]. Although the central role of exogenous PA and VA in this case was not studied, they were relevant factors in promoting tolerant capacity of rice under submergence.

Apart from phenolics, it is reported that an antioxidant enzyme system-another well-known enzymatic mechanism of plant to overcome environmental stresses-probably involving in the decrease of MDA content in rice seedlings [16,17]. The most effective enzymes consist of SOD, CAT, APX, POD, and GR. Among antioxidant enzymes, SOD is the most abundant in plant because it can be found in the cell wall, cytosol, peroxisome, microsome, apoplast, mitochoria and chloroplast of a cell [13]. In this study, the activity of most antioxidant enzymes (except GR) was significantly increased during submergence after pre-treatment with PA and VA. Apparently, the increase of some antioxidant enzyme activities was proportional to the rise of total phenolic and flavonoid contents. Particularly, the total phenolic content had high correlations to the SOD and APX activities, while total flavonoid content strongly correlated to the SOD activity (Table 2). In fact, the activities of those antioxidant enzymes and total phenolic and flavonoid contents increased during abiotic and biotic stresses, as previously 
reported [16,19-24]. For example, SOD, CAT, APX and GR activities of rice seedlings were greatly stimulated after submergence $[16,17]$. In comparison with previous works, under hypoxia stress, the activity of SOD, POD, APX and GR also increased in tomato seedlings [44]. POD activity was also enhanced in cowpea leaves after 1 day of salinity stress [45]. Fundamentally, the high activation of antioxidant enzymes assists plant to be highly tolerant or resistant to stressful conditions [44]. Additionally, the expression of gene encoding antioxidant enzymes increases proportionally to the level of oxidative stress which produces an excessive amount of reactive oxygen species [46]. Under submergence, the concentration of hydrogen peroxide, singlet oxygen, hydroxyl radicals, and superoxide in cells can dramatically increase [12,13], as chemical signals activating the expression of antioxidant enzyme genes in plant such as rice [47]. The gene expression level of antioxidant enzymes in this study was slightly elevated after rice being pre-soaked in PA and VA.

In previous reports, exogenous application of paclobutrazol (PB), a biosynthesis inhibitor of the phytohormone gibberellins (GA), was reported to promote submergence tolerance in rice [48-50]. The pretreatment $24 \mathrm{~h}$ of paclobutrazol before flooding showed significant effect on antioxidant enzymes, leaf water potential, and chlorophyll content in sweet potato [51]. However, this was the first to treat exogenous phenolic acids on rice seedlings to promote submergence tolerance, which effectively enhanced the submergence tolerance in rice. Regarding to the submergence tolerance index, the application PA and VA promoted significantly shoot elongation (Table 1). Similarly, Bailey-Serres and Voesenek [52] and Bailey-Serres et al. [53] noted that deep-water rice and most lowland rice genotypes generally adopted the submergence tolerance, characterized by the ethylene-mediated rapid elongation growth promoted by gibberellins, associated with carbohydrate consumption. In deep-water rice, the submergence tolerance was regulated by two ethylene-responsive factors (ERFs), SNORKEL1 (SK1), and SNORKEL2 (SK2), that triggered considerable internode elongation via GA during flooding [6,31]. Anandan et al. [54] highlighted that shoot elongation was an important factor adopted by rice to resume aerobic metabolism and to improve carbon fixation in submergence.

Although Setter and Leureless [48] and then Xiang et al. [50] described that PB showed a negative correlation with shoot elongation of rice, the submergence tolerance of rice was enhanced by increasing the chlorophyll contents, as also observed in this study (Figure 1). It was explained that the response to flooding by enhanced elongation ability when floodwater increases slowly resulting in a partial submergence, as it often does in deep-water and floating rice ecosystems [55]. The elongation ability reduced with consequently greater submergence tolerance when floodwater increases rapidly resulting in complete submergence, as often occurs in flash-flooding [48]. Application of PB also promoted alcohol dehydrogenase activity, and decelerated the consumption of non-structure carbohydrates, droving the expression of several submergence-related genes, such as CIPK15, MPK3, SD-1, and OsCyt-inv1, to active the corresponding pathway to enhance submergence tolerance [50]. In this study, antioxidant enzymes including SOD, CAT, APX, POD, and GR were elevated, thus the activation of submergence-related genes, which potentially differed from that of $\mathrm{PB}$ and associated to the shoot elongation of rice, should be investigated.

Although PA and VA showed effective on the stimulation of rice growth in submergence, similar examination should be conducted on other phenolic acids which were detected in anaerobic flooding tolerant rice [24], such as gallic acid, catechol, chlorogenic acid, caffeic acid, syringic acid, vanillin, $p$-coumaric acid, benzoic acid, ellagic acid, and cinnamic acid, to understand the potential of using these compounds for enhancing the submergence tolerance in rice. As observed in this study, mixture of these compounds may provide higher promotion on rice growth in submergence than the application of individual phenolic acids, apparently needs elaboration. 


\section{Materials and Methods}

\subsection{Plant Material and Treatments}

Seeds of a rice cultivar namely Koshihikari (Oryza sativa L.) harvested in affiliated fields of Hiroshima University, Japan, in 2016, were used. One hundred gram rice seeds were sterilized by soaking in $0.1 \% \mathrm{NaOCl}$ for $30 \mathrm{~min}$, and then cleaned four times in water. The seeds were then immersed in distilled water again at $30{ }^{\circ} \mathrm{C}$ for $24 \mathrm{~h}$. After that, the seeds were germinated at $30{ }^{\circ} \mathrm{C}$ in a growth chamber without light. Germinated seeds were separately placed into seedling trays filled with nutrient soil, and grown in a net house for 3 weeks. Subsequently, roots of rice seedlings were soaked in different dilution of 1, 0.1 and $0.01 \mathrm{mM}$ solutions of PA, VA and their corresponding mixtures for $24 \mathrm{~h}$. All treated seedlings were transferred to a water tank $(100 \mathrm{~cm} \times 200 \mathrm{~cm} \times 80 \mathrm{~cm}$ of width $\times$ length $\times$ height) for submergence treatment. The seedlings were placed at $20 \mathrm{~cm} \times 10 \mathrm{~cm}$ density (total 90 rice seedling per tank), conducted in thrice and repeat twice. After each 3 and six days of submergence, leaves and roots were collected, washed with tap water and then stored at $-20{ }^{\circ} \mathrm{C}$ for further analysis. The shoot elongation $(\mathrm{cm})$ was measured after de-submerged for 10 days (Table 1). The survival percentages and scores were evaluated according a method described in the International Rice Research Institute (IRRI) [56]. The survival percentage was determined as the plant numbers excluding from death rice seedlings during submergence treatment against total experimented plant numbers. Of which, the scale for scoring submergence included 1: survival 100\%; 3: survival 95-99\%; 5: survival 75-94\%; 7: survival 50-75\%; and 9: survival 0-49\% (Table A1).

\subsection{Lipid Peroxidation Measurement}

Lipid Peroxidation (LP) was estimated via the MDA content [57] with some minor modifications. An amount of $0.4 \mathrm{~g}$ frozen leaves was ground with $2 \mathrm{~mL}$ of $0.5 \%$ trichloroacetic acid (TCA) using a pestle and mortar, and the mixture was centrifuged for $10 \mathrm{~min}$ at 10,000 rpm. The supernatant was transferred to a new tube, and a volume of $20 \%$ TCA including thiobarbituric acid was added in the tube which were later incubated at $95{ }^{\circ} \mathrm{C}$ for a half-hour and immediately placed in a beaker containing ice. The reaction solution was spectrophotometrically (TU-1800 PC UV-vis spectrophotometer, Shimadzu, Co., Ltd., Tokyo, Japan) recorded at $532 \mathrm{~nm}$, and the absorbance values were used for calculation the MDA content based on an extinction coefficient $\left(155 \mathrm{mM}^{-1} \mathrm{~cm}^{-1}\right)$.

\subsection{Measurement of Chlorophyll Contents}

Chlorophyll contents were quantified according to the method described by Quan et al. [58]. An amount $500 \mathrm{mg}$ of leaves was ground in $2 \mathrm{~mL}$ of $85 \%$ acetone using a mortar and pestle. The mixture was then centrifuged at $5000 \mathrm{rpm}$ for $5 \mathrm{~min}$. A volume of the above layer $(0.5 \mathrm{~mL})$ was transferred to a new tube and diluted with acetone solution for measuring the absorbance at two wavelengths $(644$ and $663 \mathrm{~nm})$. Contents of chlorophylls a and b (mg/g fresh weight (FW)) were estimated according to the following formulas:

$$
\begin{aligned}
& \text { Chlorophyll } a=10.3 \times \mathrm{Abs}_{663}-0.918 \times \mathrm{Abs}_{644} \\
& \text { Chlorophyll } b=19.7 \times \mathrm{Abs}_{644}-3.87 \times \mathrm{Abs}_{663}
\end{aligned}
$$

\subsection{Estimation of Total Phenolic and Flavonoid Contents}

Total contents of phenolics and flavonoids were spectrophotometrically estimated followed the methods of Khang et al. [24]. Total phenolic and flavonoid contents were shown as mg gallic acid equivalents (GAE) per gram dry weight (DW) and mg of rutin equivalents (RE) per gram DW, respectively. 


\subsection{Identification and Quantification of Protocatechuic Acid and Vanillic Acid}

The column C18 $(5 \mu \mathrm{m} \times 0.46 \mathrm{~cm} \times 25 \mathrm{~cm})$ connected to the HPLC (JASCO, Tokyo, Japan) system with a LC-Net II/ADC controller, a PU-2089 pump and an UV-2075 detector was used for quantifying the concentrations of PA and VA. The leaf and root extracts in methanol $(1 \mathrm{mg} / \mathrm{mL})$ were filtered, and a volume of $5 \mu \mathrm{L}$ was injected. A gradient elution of absolute methanol (A) and $0.1 \%$ acid acetic (B) was run at $1 \mathrm{~mL} / \mathrm{min}$ speed with a linear increase of A from $5-10 \%$ for $5 \mathrm{~min}$, then 10-90\% for $45 \mathrm{~min}$, and 10 min cleaning step with only solvent A. The phenolic standard curves were established from different concentrations from 0 to $100 \mu \mathrm{g} / \mathrm{mL}$ for quantification of identified phenolics in the samples.

\subsection{Enzyme Extraction and Assays}

An amount of $0.1 \mathrm{~g}$ leaves was homogenized with $1800 \mu \mathrm{L}$ of $\mathrm{PB}(\mathrm{pH}$ 6.8) and $200 \mu \mathrm{L}$ of $1 \mathrm{mM}$ ethylenediaminetetraacetic acid (EDTA). The mixture was centrifuged for $20 \mathrm{~min}$ at 15,000 rpm, and the upper portion was kept at $-20^{\circ} \mathrm{C}$ for further measurement. APX activity was evaluated using the method described by Nakano and Asada [59] with several changes. A volume of 0.6 mL of 0.05 M PB (pH 7.0), $0.1 \mathrm{~mL}$ of $0.001 \mathrm{M}$ EDTA, $0.1 \mathrm{~mL}$ of $0.005 \mathrm{M}$ ascorbate, $100 \mu \mathrm{L}$ of enzyme extracts, and $0.1 \mathrm{~mL} 1 \mathrm{mM} \mathrm{H}_{2} \mathrm{O}_{2}$ were added in a reaction tube, and then the reaction mixture was immediately measured at $29 \mathrm{~nm}$ for three minutes. The APX activity was calculated using the extinction coefficient $\left(2.8 \mathrm{mM}^{-1} \mathrm{~cm}^{-1}\right)$ and expressed as unit/min/g FW. CAT activity was estimated by measuring the decrease of hydrogen peroxide [16]. The reaction included $1.5 \mathrm{~mL} 0.1 \mathrm{M} \mathrm{PB}(\mathrm{pH} 7.0), 950 \mu \mathrm{L}$ distilled water, $50 \mu \mathrm{L}$ enzyme extracts, and $0.5 \mathrm{~mL}$ of $75 \mathrm{mM} \mathrm{H}_{2} \mathrm{O}_{2}$. The reduction of $\mathrm{H}_{2} \mathrm{O}_{2}$ was recorded at $240 \mathrm{~nm}$ for $3 \mathrm{~min}$, and the CAT activity was calculated using the extinction coefficient $\left(6.93 \times 10^{-3} \mathrm{mM}^{-1} \mathrm{~cm}^{-1}\right)$ and expressed as unit $/ \mathrm{min} / \mathrm{g}$ FW. Activity of SOD was assayed based on the reaction of riboflavin and nitro blue tetrazolium (NBT) [60]. The reaction included $1.5 \mathrm{~mL}$ of $0.05 \mathrm{M} \mathrm{PB}$ (pH 7.8), $1 \mathrm{~mL}$ distilled water, $100 \mu \mathrm{L}$ of $3 \mathrm{mM}$ EDTA, $100 \mu \mathrm{L}$ of $200 \mathrm{mM}$ L-methionine, $10 \mu \mathrm{L}$ of $2.25 \mathrm{mM}$ NBT, $50 \mu \mathrm{L}$ enzyme extracts, and $100 \mu \mathrm{L}$ riboflavin in a test tube. After shaking, the reaction was initiated by placing under a lamp (15 W) for $15 \mathrm{~min}$. The control was the mixture without the enzyme extract, and the blank containing the same ingredients with those of the control was not placed under the lamp. The SOD activity was calculated by the subtraction of the control to the sample, and expressed as unit/g FW. POD activity was measured by guaiacol method with some changes [61]. The reaction mixture consisted of $150 \mu \mathrm{L}$ of $4 \%$ guaiacol, $150 \mu \mathrm{L}$ of $1 \% \mathrm{H}_{2} \mathrm{O}_{2}$, $2.66 \mathrm{~mL}$ of phosphate buffer ( $\mathrm{pH} 7.0$ ), and $40 \mu \mathrm{L}$ of enzyme extracts. The absorption was recorded at $465 \mathrm{~nm}$ for $180 \mathrm{~s}$. The POD activity was calculated based on the extinction coefficient $\left(25 \mathrm{mM}^{-1} \mathrm{~cm}^{-1}\right)$ and shown as unit/min/g FW. GR activity was estimated based on the modified method of Foyer and Halliwell [62]. The reaction contained $0.6 \mathrm{~mL}$ of $50 \mathrm{mM}$ PB (pH 7.6), $0.1 \mathrm{~mL}$ of EDTA (0.003 M), $0.1 \mathrm{~mL}$ of $100 \mu \mathrm{M}$ dihydronicotinamide-adenine dinucleotide phosphate (NADPH), $0.1 \mathrm{~mL}$ of $0.001 \mathrm{mM}$ glutathione disulfide (GSSG), and $0.1 \mathrm{~mL}$ of enzyme extract. The reaction absorbance was read at $340 \mathrm{~nm}$ for $180 \mathrm{~s}$. The activity was calculated using the extinction coefficient $\left(6.2 \mathrm{mM}^{-1} \mathrm{~cm}^{-1}\right)$ for GSSG and shown as unit/min/g FW.

\subsection{Gene Expression of Antioxidant Enzymes Using Quantitative Real-Time PCR}

The total RNA in leaves was isolated using the RN-Sure Plant Kit (Apro Science, Tokushima, Japan) for examining the gene expression of antioxidant enzyme genes, following manufacturer's instructions. An amount of $1 \mu \mathrm{g}$ total RNA was used for synthesizing cDNA using the SuperScript III First-Strand Synthesis System for RT-PCR (Invitrogen, Carlsbad, CA, USA). After diluted to $100 \mathrm{ng}$, a volume of $2 \mu \mathrm{L}$ cDNA of each treatment was added to a real-time PCR plate containing $6 \mu \mathrm{L}$ KAPA SYBR FASTqPCR MasterMix (2X) Universal and primers $(1 \mu \mathrm{L}$ of each forward and reverse primer $(10 \mu \mathrm{M}))$. The PCR plate was covered by a transparent film and run in the StepOne real-time PCR system (Applied Biosystem Corp., Foster City, CA, USA). The program was set for enzyme activation at $95^{\circ} \mathrm{C}$ for $30 \mathrm{~s}$, followed by 40 cycles of denaturing at $95^{\circ} \mathrm{C}$ for $5 \mathrm{~s}$ and annealing at $60{ }^{\circ} \mathrm{C}$ for $60 \mathrm{~s}$. The list of primers is shown in Table 3. 
Table 3. Primer sequences of the selected antioxidant enzyme genes.

\begin{tabular}{cc}
\hline Genes & \multicolumn{1}{c}{ Primer Sequences } \\
\hline SOD & $\begin{array}{c}\text { Forward: GGCTTGCATACAAACCTGAA } \\
\text { Reverse: CTGACTGCTTCCCATGACACCAT }\end{array}$ \\
\hline CAT & $\begin{array}{c}\text { Forward: GTCGATTGGTGTTGAACAGG } \\
\text { Reverse: AGGACGACAAGGATCAAACC }\end{array}$ \\
\hline APX & $\begin{array}{c}\text { Forward: GACTCTTGGAGCCCATTAGG } \\
\text { Reverse: AGGGTGAAAGGGAACATCAG }\end{array}$ \\
\hline POD & $\begin{array}{c}\text { Forward: TTAGGGAGCAGTTTCCCACT } \\
\text { Reverse: AGGGTGAAAGGGAACATCAG }\end{array}$ \\
\hline GR & $\begin{array}{c}\text { Forward: TTGGTGGAACGTGTGTTCTT } \\
\text { Reverse: TCTCATTCACTTCCCATCCA }\end{array}$ \\
\hline Actin & $\begin{array}{c}\text { Forward: TGGTCGGAATGGGACAGAAG } \\
\text { Reverse: CTCAGTCAGGAGAACAGGGT }\end{array}$ \\
\hline
\end{tabular}

\subsection{Statistical Analyses}

All data were statistically analyzed using one-way analysis of variance (ANOVA), and Tukey's test was used to compared means using the Minitab 16.0 (Minitab Inc.; State College, PA, USA). Comparisons with $p<0.05$ were considered significantly different. Pearson's correlation coefficients (r) among parameters were calculated using SPSS software 18.0 (Chicago, IL, USA). The mRNA increase was estimated using the $\Delta C T$ (delta threshold cycle) method [63].

\section{Conclusions}

Enhancement of the antioxidant enzyme system during submergence using chemical treatment is an innovative approach. The use of PA and VA and their mixture was promising for improving rice growth in submergence. This study helped to clarify the effects of exogenous PA and VA on both enzymatic and non-enzymatic antioxidant systems of rice during submergence. Application of mixture of PA and VA were effective and economically efficacious to enhance the submergence tolerance. However, further trials should be performed to examine how PA and VA respond to different water depths, which may help to understand the actual role of the two compounds in strengthening submergence tolerance in rice.

Author Contributions: D.T.K. and T.D.X. conceived and designed the experiments. D.T.K. carried out the experiments. T.D.X. analyzed the data and revised the manuscript.

Conflicts of Interest: The authors declare no conflict of interest.

\section{Appendix}

Table A1. Scale for scoring submergence tolerance of rice.

\begin{tabular}{cc}
\hline Scale & Survival (\%) \\
\hline 1 & 100 \\
3 & $95-99$ \\
5 & $75-94$ \\
7 & $50-75$ \\
9 & $0-49$ \\
\hline
\end{tabular}

The rice seedlings were de-submerged for 10 days, and then recorded the plant height and scored according to IRRI's method (IRRI, 2002). 


\section{References}

1. Ismail, A.M.; Singh, U.S.; Sing, S.; Dar, M.H.; Mackill, D.J. The contribution of submergence-tolerant (Sub1) rice varieties to food security in flood-prone rainfed lowland areas in Asia. Field Crops Res. 2013, 152, 83-93. [CrossRef]

2. Mackill, D.J.; Ismail, A.M.; Pamplona, A.M.; Sanchez, D.L.; Carandang, J.J.; Septiningsih, E.M. Stress tolerant rice varieties for adaptation to a changing climate. Crop Environ. Bioinform. 2010, 7, 250-259.

3. Wassmann, R.; Jagadish, S.V.K.; Sumfleth, K.; Pathak, H.; Howell, G.; Ismail, A.; Heuer, S. Chapter 3: Regional vulnerability of climate change impacts on Asian rice production and scope for adaptation. Adv. Agron. 2009, 102, 91-133.

4. Xu, K.; Mackill, D.J. A major locus for submergence tolerance mapped on rice chromosome 9. Mol. Breed. 1996, 2, 219-224. [CrossRef]

5. Xu, K.; Xia, X.; Fukao, T.; Canlas, P.; Maghirang-Rodriguez, R.; Heuer, S.; Ismail, A.M.; Bailey-Serres, J.; Ronald, P.C.; Mackill, D.J. Sub1A is an ethylene response factor-like gene that confers submergence tolerance to rice. Nature 2006, 442, 705-708. [CrossRef] [PubMed]

6. Hattori, Y.; Nagai, K.; Furukawa, S.; Song, X.J.; Kawano, R.; Sakakibara, H.; Wu, J.Z.; Matsumoto, T.; Yoshimura, A.; Kitano, H.; et al. The ethylene response factors SNORKEL1 and SNORKEL2 allow rice to adapt to deep water. Nature 2009, 460, 1026-1031. [CrossRef] [PubMed]

7. Sharma, A.R.; Ghosh, A. Submergence tolerance and yield performance of lowland rice as affected by agronomic management practices in eastern India. Field Crops Res. 1999, 63, 187-198. [CrossRef]

8. Septiningsih, E.M.; Pamplona, A.M.; Sanchez, D.L.; Neeraja, C.N.; Vergara, G.V.; Heuer, S.; Mackill, D.J. Development of submergence-tolerant rice cultivars: The Sub1 locus and beyond. Ann. Bot. 2009, 103, 151-160. [CrossRef] [PubMed]

9. Liu, M.; Chu, M.; Ding, Y.; Wang, S.; Liu, Z.; Tang, S.; Li, G. Exogenous spermidine alleviates oxidative damage and reduce yield loss in rice submerged at tillering stage. Front. Plant Sci. 2015, 6, 919. [CrossRef] [PubMed]

10. Gratão, P.L.; Polle, A.; Lea, P.J.; Azevedo, R.A. Making the life of heavy metal-stressed plants a little easier. Funct. Plant Biol. 2005, 32, 481-494. [CrossRef]

11. Alyemeni, M.N.; Hayat, Q.; Wijaya, L.; Hayat, S. Effect of salicylic acid on the growth, photosynthetic efficiency and enzyme activities of leguminous plant under cadmium stress. Not. Bot. Horti Agrobot. 2014, 42, 440-445. [CrossRef]

12. Foyer, C.H.; Noctor, G. Redox sensing and signalling associated with reactive oxygen in chloroplasts, peroxisomes and mitochondria. Physiol. Plant 2003, 119, 355-364. [CrossRef]

13. Alscher, R.G.; Erturk, N.; Heath, L.S. Role of superoxide dismutases (SODs) in controlling oxidative stress in plants. J. Exp. Bot. 2002, 53, 1331-1341. [CrossRef] [PubMed]

14. Bowler, C.; Montagu, M.V.; Inze, D. Superoxide dismutase and stress tolerance. Annu. Rev. Plant Physiol. Plant Mol. Biol. 1992, 43, 83-116. [CrossRef]

15. Asada, K. The water-water cycle in chloroplasts: Scavenging of active oxygens and dissipation of excess photons. Annu. Rev. Plant Physiol. Plant Mol. Biol. 1999, 50, 601-639. [CrossRef] [PubMed]

16. Damanik, R.I.; Maziah, M.; Ismail, M.R.; Ahmad, S.; Zain, A.M. Responses of the antioxidative enzymes in Malaysian rice (Oryza sativa L.) cultivars under submergence condition. Acta Physiol. Plant 2010, 32, 739-747. [CrossRef]

17. Anandan, A.; Arunachalam, P. Relative proportion of antioxidative enzyme activity in locally grown Indian rice cultivars (Oryza sativa L.) under submergence condition. J. Plant Interact. 2012, 7, 183-192. [CrossRef]

18. Cheynier, V. Phenolic compounds: From plants to foods. Phytochem. Rev. 2012, 11, 153-177. [CrossRef]

19. Clé, C.; Hill, L.M.; Niggeweg, R.; Martin, C.R.; Guisez, Y.; Prinsen, E.; Jansen, M.A.K. Modulation of chlorogenic acid biosynthesis in Solanum lycopersicum; consequences for phenolic accumulation and UV-tolerance. Phytochemistry 2008, 69, 2149-2156. [CrossRef] [PubMed]

20. Schmitz-Hoerner, R.; Weissenbock, G. Contribution of phenolic compounds to the UV-B screening capacity of developing barley primary leaves in relation to DNA damage and repair under elevated UV-B levels. Phytochemistry 2003, 64, 243-255. [CrossRef] 
21. Yan, K.; Zhao, S.; Bian, L.; Chen, Z. Saline stress enhanced accumulation of leaf phenolics in honeysuckle (Lonicera japonica Thunb.) without induction of oxidative stress. Plant Physiol. Biochem. 2017, 112, 326-334. [CrossRef] [PubMed]

22. Minh, L.T.; Khang, D.T.; Ha, P.T.T.; Tuyen, P.T.; Minh, T.N.; Quan, N.V.; Xuan, T.D. Effects of salinity stress on growth and phenolics of rice (Oryza sativa L.). Int. Lett. Nat. Sci. 2016, 57, 1-10. [CrossRef]

23. Quan, N.T.; Anh, L.H.; Khang, D.T.; Tuyen, P.T.; Toan, N.P.; Minh, T.N.; Xuan, T.D. Involvement of secondary metabolites in response to drought stress of rice (Oryza sativa L.). Agriculture 2016, 6, 23. [CrossRef]

24. Khang, D.T.; Ha, P.T.T.; Lang, N.T.; Tuyen, P.T.; Minh, L.T.; Minh, T.N.; Xuan, T.D. Involvement of phenolic compounds in anaerobic flooding germination of rice (Oryza sativa L.). Int. Lett. Nat. Sci. 2016, 56, 73-81. [CrossRef]

25. Gautam, P.; Nayak, A.K.; Lal, B.; Bhattacharyya, P.; Tripathi, R.; Shahid, M.; Mohanty, M.; Raja, R.; Panda, B.B. Submergence tolerance in relation to application time of nitrogen and phosphorus in rice (Oryza sativa L.). Environ. Exp. Bot. 2014, 99, 159-166. [CrossRef]

26. Metraux, J.P.; Kende, H. The role of ethylene in the growth response of submerged deep water rice. Plant Physiol. 1983, 72, 441-446. [CrossRef] [PubMed]

27. Ella, E.S.; Ismail, A.M. Seedling nutrient status before submergence affects survival after submergence in rice. Crop Sci. 2006, 46, 1673-1681. [CrossRef]

28. Ella, E.S.; Kawano, N.; Yamauchi, Y.; Ismail, A.M. Blocking ethylene perception enhances flooding tolerance in rice seedlings. Funct. Plant Biol. 2003, 30, 813-819. [CrossRef]

29. Ahmed, S.; Nawata, E.; Hosokawa, M.; Domae, Y.; Sakuratani, T. Alterations in photosynthesis and some antioxidant enzymatic activities of mungbean subjected to waterlogging. Plant Sci. 2002, 163, 117-123. [CrossRef]

30. Voesenek, L.A.C.J.; Colmer, T.D.; Pierik, R.; Millenaar, F.F.; Peeters, A.J.M. How plants cope with complete submergence. New Phytol. 2006, 170, 213-226. [CrossRef] [PubMed]

31. Hattori, Y.; Nagai, K.; Ashikari, M. Rice growth adapting to deepwater. Curr. Opin. Plant Biol. 2011, 14, 100-105. [CrossRef] [PubMed]

32. Armstrong, W. Aeration in higher plants. Adv. Bot. Res. 1979, 7, 225-332.

33. Sarkar, R.K.; Das, S.; Ravi, I. Changes in certain antioxidative enzymes and growth parameters as a result of complete submergence and subsequent re-aeration of rice cultivars differing in submergence tolerance. J. Agron. Crop Sci. 2001, 187, 69-74. [CrossRef]

34. Sarkar, R.K.; Reddy, J.N.; Sharma, S.G.; Ismail, A.M. Physiological basis of submergence tolerance in rice and implications for crop improvement. Curr. Sci. 2006, 91, 899-906.

35. Wu, Y.S.; Yang, C.Y. Physiological responses and expression profile of NADPH oxidase in rice (Oryza sativa) seedlings under different levels of submergence. Rice 2016, 9, 2. [CrossRef] [PubMed]

36. Belkhadi, A.; Hediji, H.; Abbes, Z.; Nouairi, I.; Barhoumi, Z.; Zarrouk, M.; Djebali, W. Effects of exogenous salicylic acid pre-treatment on cadmium toxicity and leaf lipid content in Linum usitatissimum L. Ecotoxicol. Environ. Saf. 2010, 73, 1004-1011. [CrossRef] [PubMed]

37. Fang, Z.; Bouwkamp, J.C.; Solomos, T. Chlorophyllase activities and chlorophyll degradation during leaf senescence in non-yellowing mutant and wild type of Phaseolus vulgaris L. J. Exp. Bot. 1998, 49, 503-510.

38. Yang, C.M.; Chang, I.F.; Lin, S.J.; Chou, C.H. Effects of three allelopathic phenolics on chlorophyll accumulation of rice (Oryza sativa) seedlings: II. Stimulation of consumption-orientation. Bot. Bull Acad. Sin. 2004, 45, 119-125.

39. Davey, M.W.; Stals, E.; Panis, B.; Keulemans, J.; Swennen, R.L. High-throughput determination of malondialdehyde in plant tissues. Anal. Biochem. 2005, 347, 201-207. [CrossRef] [PubMed]

40. Lu, P.; Sang, W.G.; Ma, K.P. Differential responses of the activities of antioxidant enzymes to thermal stresses between two invasive Eupatorium species in China. J. Integr. Plant Biol. 2008, 50, 393-401. [CrossRef] [PubMed]

41. Michalak, A. Phenolic compounds and their antioxidant activity in plants growing under heavy metal stress. Pol. J. Environ. Stud. 2006, 15, 523-530.

42. Milić, B.L.; Djilas, S.M.; Čanadanović-Brunet, J.M. Antioxidative activity of phenolic compounds on the metal-ion breakdown of lipid peroxidation system. Food Chem. 1998, 61, 443-447. [CrossRef] 
43. Chou, T.H.; Ding, H.Y.; Hung, W.J.; Liang, C.H. Antioxidative characteristics and inhibition of $\alpha$-melanocyte-stimulating hormone-stimulated melanogenesis of vanillin and vanillic acid from Origanum vulgare. Exp. Dermatol. 2010, 19, 742-750. [CrossRef] [PubMed]

44. Liu, A.; Chen, S.; Mi, Y.; Zhou, Z.; Ahammed, G.J. Effects of hypoxia stress and different level of $\mathrm{Mn}^{2+}$ on antioxidant enzyme of tomato seedlings. Am. J. Plant Sci. 2010, 1, 24-31. [CrossRef]

45. Cavalcanti, F.R.; Oliveira, J.T.A.; Martins-Miranda, A.S.; Viégas, R.A.; Silveira, J.A.G. Superoxide dismutase, catalase and peroxidase activities do not confer protection against oxidative damage in salt-stressed cowpea leaves. New Phytol. 2004, 163, 563-571. [CrossRef]

46. Michiels, C.; Raes, M.; Toussaint, O.; Remacle, J. Importance of Se-glutathione peroxidase, catalase, and $\mathrm{Cu} / \mathrm{Zn}-\mathrm{SOD}$ for cell survival against oxidative stress. Free Radic. Biol. Med. 1994, 17, 235-248. [CrossRef]

47. Espinosa-Diez, C.; Miguel, V.; Mennerich, D.; Kietzmann, T.; Sánchez-Pérez, P.; Cadenas, S.; Lamas, S. Antioxidant responses and cellular adjustments to oxidative stress. Redox Biol. 2015, 6, 183-197. [CrossRef] [PubMed]

48. Setter, T.L.; Laureles, E.V. The beneficial effect of reduced elongation growth on submergence tolerance of rice. J. Exp. Bot. 1996, 47, 1551-1559. [CrossRef]

49. Elanchezhian, R.; Haris, A.A.; Kumar, S.; Singh, S.S. Positive impact of paclobutrazol on gas exchange, chlorophyll fluorescence and yield parameters under submergence stress in rice. Indian J. Plant Physiol. 2015, 20, 111-115. [CrossRef]

50. Xing, J.; Wu, H.; Zhang, Y.; Zhang, Y.; Wang, Y.; Li, Z.; Lin, H.; Chen, H.; Zhang, J.; Zhu, D. Transcriptomic analysis of gibberellin- and paclobutrazol-treated rice seedlings under submergence. Int. J. Mol. Sci. 2017, 18, 2225. [CrossRef] [PubMed]

51. Lin, K.H.; Tsou, C.C.; Hwang, S.Y.; Chen, L.F.; Lo, H.F. Paclobutrazol lead to enhanced antioxidative protection of sweet potato under flooding stress. Bot. Stud. 2008, 49, 9-18.

52. Bailey-Serres, J.; Voesenek, L.A.C.J. Flooding stress: Acclimations and genetic diversity. Annu. Rev. Plant Biol. 2008, 59, 313-339. [CrossRef] [PubMed]

53. Bailey-Serres, J.; Fukao, T.; Ronald, P.; Ismail, A.; Heuer, S.; Mackill, D. Submergence tolerant rice: SUB1's journey from landrace to modern cultivar. Rice 2010, 3, 138-147. [CrossRef]

54. Anandan, A.; Rajiv, G.; Ramarao, A.; Prakash, M. Internode elongation pattern and differential response of rice genotypes to varying levels of flood water. Funct. Plant Biol. 2012, 39, 137-145. [CrossRef]

55. Catling, D. Rice in Deep Water; International Rice Research Institute: Manila, Philippines, 1992; 542p.

56. IRRI (International Rice Research Institute). Standard Evaluation System for Rice, 3rd ed.; International Rice Research Institute: Los Banos, Philippines, 2002; 56p. Available online: http:/ / www.knowledgebank.irri. org/images/docs/rice-standard-evaluation-system.pdf) (accessed on 15 December 2017).

57. Demiral, T.; Türkan, İ. Comparative lipid peroxidation, antioxidant defense systems and proline content in roots of two rice cultivars differing in salt tolerance. Environ. Exp. Bot. 2005, 53, 247-257. [CrossRef]

58. Quan, N.V.; Khang, D.T.; Dep, L.T.; Minh, T.N.; Nobukazu, N.; Xuan, T.D. The potential use of a food-dyeing plant Peristrophe bivalvis (L.) Merr. in Northern Vietnam. Int. J. Pharmacol. Phytochem. Ethnomed. 2016, 4, 14-26. [CrossRef]

59. Nakano, Y.; Asada, K. Hydrogen peroxide is scavenged by ascorbate-specific peroxidase in spinach chloroplasts. Plant Cell Physiol. 1981, 22, 867-880.

60. Beauchamp, C.; Fridovich, I. Superoxide dismutase: Improved assays and an assay applicable to acrylamide gels. Anal. Biochem. 1971, 44, 276-287. [CrossRef]

61. Herzog, V.; Fahimi, H. Determination of the activity of peroxidase. Anal. Biochem. 1973, 55, 554-562. [CrossRef]

62. Foyer, C.H.; Halliwell, B. The presence of glutathione and glutathione reductase in chloroplasts: A proposed role in ascorbic acid metabolism. Planta 1976, 133, 21-25. [CrossRef] [PubMed]

63. Livak, K.J.; Schmittgen, T.D. Analysis of relative gene expression data using real-time quantitative PCR and the $2^{-\Delta \Delta \mathrm{CT}}$ method. Methods 2001, 25, 402-408. [CrossRef] [PubMed]

(C) 2018 by the authors. Licensee MDPI, Basel, Switzerland. This article is an open access article distributed under the terms and conditions of the Creative Commons Attribution (CC BY) license (http:/ / creativecommons.org/licenses/by/4.0/). 